Іәнатов О.М., Григор'єв П.Є. Можливий вплив геліогеофізичних фракторів на організм майбутніх злочинців...

Резюме

Загиней 3. А. Правовая экспертиза как средство выявления недостатков текста уголовного закона Украины: общетеоретический аспект.

В статье уделено внимание общетеоретических аспектам правовой экспертизы как средства выявления недостатков текста уголовного закона Украины. Выделены узкое и широкое значение понятия «правовая экспертиза». Доказано, что правовая экспертиза в правотворческом процессе имеет тот потенциал, который может исправить недостатки текста уголовного закона Украины. Правовая экспертиза - это специфический элемент правоинтерпретационной деятельности, поскольку осуществляется до принятия уголовного закона Украины. При проведении правовой экспертизы должны применяться те же методы герменевтического анализа текста уголовного закона, что и при осуществлении правоприменительной практики. Проанализированы суть и значение антикоррупционной экспертизы в правотворческом процессе.

Ключевые слова: правовая экспертиза; антикоррупционная экспертиза; текст уголовного закона Украины; недостатки текста уголовного закона Украины; юридическая техника; герменевтика; толкование.

\title{
Summary
}

Zagyney $Z$. Legal expertise as a means to identify shortcomings of the text of the criminal law of Ukraine: general theoretical aspect.

The paper paid attention to the problem of the general theoretical aspects of legal expertise as a means to identify deficiencies of the text of the criminal law of Ukraine. Marked with narrow and broad meaning of «legal expertise».Proved that the legal expertise in law-making process has the potential, which can correct the flaws of the text of the criminal law of Ukraine. Legal expertise - this is a specific element of interpretive activities, as implemented pending the criminal law of Ukraine. When conducting legal expertise should apply the same methods of hermeneutical analysis of the text of criminal law, and that in the exercise of law enforcement. Analyzed the nature and meaning of anti-corruption expertise in the law-making process.

Key words: legal expertise; anti-corruption expertise, the text of the criminal law of Ukraine; shortcomings text of the criminal law of Ukraine; legal technique hermeneutic; interpretation.

Отримано 21.11.2013

О. М. ІГНАТОВ, П. Є. ГРИГОР'ЄВ

Олександр Миколайович Іанатов, кандидат юридичних наук, старший науковий співробітник, доцент Одеського державного університету внутрішніх справ

Павло Євгенович Григор'єв, доктор біологічних наук, доцент, завідувач кафедри Державної установи «Кримський державний медичний університет імені С. І. Георгієвського»

\section{МОЖЛИВИЙ ВПЛИВ ГЕЛІОГЕОФІЗИЧНИХ ФАКТОРІВ НА ОРГАНІЗМ МАЙБУТНІХ ЗЛОЧИНЦІВ У РАННЬОМУ ОНТОГЕНЕЗІ}

Сьогодні кримінологи, досліджуючи фактори детермінації злочинності, майже повністю ігнорують роль факторів природного середовища, незважаючи на те, що на них 3 давніх часів періодично звертають увагу фахівці гуманітарних та природничих наук.

Усі соціально-психологічні явища і процеси, які відіграють роль у детермінації злочинності, формуються й існують під впливом природних екологічних факторів, тому вказані фактори (насамперед, геліогеофізичні і пов'язані з ними метеорологічні) відіграють роль об'єктивної умови. Щодо рівня окремого злочину, дані фактори середовища можуть відігравати роль суб'єктивної передумови (що особливо характерно для тяжких і особо тяжких насильницьких злочинів, які вчинюються особами з аномаліями психіки), а так само разом з іншими факторами можуть формувати конкретну життєву ситуацію вчинення злочину ${ }^{1}$.

Говорячи про роль факторів навколишнього (природного) середовища в детермінації злочинності, передусім, необхідно враховувати вплив космофізичних факторів, що викликають нині найбільший науковий інтерес. На стан готовності людини до скоєння злочину поряд з біологічними, психофізіологічними та соціальними факторами діють планетарні геліогеофізичні фактори (далі - ГГФ). Їх вплив зумовлюється тим, що вони є одним із первинних екологічних факторів і мають надзвичайну психотропність, впливаючи на динаміку психічних станів, зокрема збудливість, тривожність, агресивність, імпульсивність тощо ${ }^{2}$.

(C) О. М. Ігнатов, П. Є. Григор'єв, 2013 
Відмінною рисою ГГФ є наявність глобальної складової і синхронність їі дії в планетарному масштабі. На відміну від локальних погодних факторів, космофізичні фактори діють практично повсюдно в біосфері. Основними факторами космічної погоди є процеси за межами Сонячної системи і на Сонці: електромагнітне випромінювання й потоки частинок в міжпланетному просторі. При взаємодії з оболонками Землі (магнітосфера, іоносфера) ці фактори зрештою перетворюються на екологічно значущі зміни електромагнітного, акустичного і радіаційного фону навколоземного простору.

Зміни в електромагнітно-акустичному фоні середовища через дію ГГФ відбуваються на резонансних для систем організму і біохімічних реакцій частотах ${ }^{3}$ і тим самим здійснюють керуючий вплив на стан організму. Доведено, що біологічні ритми систем організму людини і тварин пов'язані з поточним станом та змінами геліогеофізичної обстановки в діапазоні від декількох годин до багатьох років ${ }^{4}$

У різних кліматичних та екологічних умовах встановлено ідентичні ефекти впливу ГГФ на сплески психічних, нервових захворювань 5 , а також на скоєння суїцидів ${ }^{6}$, насильницьких злочинів ${ }^{7}$, терористичних актів ${ }^{8}$.

Не тільки багаторічні зміни ГГФ на етапах раннього розвитку впливають на властивості організму, але й більш короткочасні їх варіації на певних етапах онтогенезу - гаметогенезу, запліднення, окремих стадій вагітності, народження, та ін. Як вказує О. Д. Волчек, «вже до моменту зачаття перевагу отримують статеві клітини наступного зародку з генотипом, оптимально адаптованим до наступних умов довкілля, а мінливість сонячної й геомагнітної активності... служать... інформаційним сигналом щодо наступних погодних змін... Таким чином зростас різноманіття типів людини на генетичному, конституціональному, нейрофізіологічному, особистому та інших рівнях, стійкість існування людини на Землі»9. Ймовірно, таке пристосування можуть забезпечити, у тому числі, процеси геномного імпринтингу 10 за умов чутливості цих процесів до ГГФ. Сила нервової системи людини корелює з (далі - СА) (сонячною активністю) в рік народження - індивіди з сильним та середнє-сильним типами нервової системи (далі - НC) народжуються частіше у роки максимумів СА, і навпаки, особи зі слабим та середнє-слабим типами - в роки мінімумів СА ${ }^{11}$. Отже, встановлено, що статеві клітини і процеси гаметогенезу є чутливими до чинників довкілля. Особливо це стосується подальшого ризику виникнення психічних і нервових захворювань.

Встановлено, що існує тісний статистичний зв'язок $(\mathrm{r}=+0.82)$ ризику захворювання шизофренією 3 рівнем СА в період пренатального розвитку ${ }^{12}$. У дослідженнях Н. А. Корнетова і співавторів ${ }^{13}$ було показано, що значення СА на 2 і 5 місяцях ембріогенезу хворих на недиференційовану олігофренію істотно перевищували ті ж значення для контрольної групи здорових людей аналогічного віку. Підвищена СА протягом першого, другого та шостого місяців ембріогенезу, на думку В. П. Ісхакова, є своєрідним поштовхом для переходу шизофренії з пасивної форми до активної14 R. C. Richardson-Andrews пояснює зв'язок зростання ймовірності розвитку шизофренії в осіб, народжених в роки з підвищеними СА і геомагнітною активністю (далі - ГМА), зменшенням продукції мелатоніну у вагітних через підвищену ГМА, що, в свою чергу, спричиняє відповідне порушення у плоду.

Серед можливих каналів впливу ГГФ в гаметогенезі та ембріогенезі на формування порушень організму слід назвати не тільки опосередковану дію ГГФ на гамети і зародок через зміни станів регуляторних систем організму батьків, а й пряму дію фізичних агентів ГГФ на клітини і структури ембріону. Адже існує залежність кількості хромосомних аберацій у соматичних клітинах людини від варіацій ГМП 15 . Вченими обгрунтовується вірогідність впливу факторів низькоенергетичної природи на генетичний апарат через низку механізмів, зокрема, через зміни в експресії генів ${ }^{16}$.

Поряд 3 дослідженнями зв'язків даних популяційної та медичної статистики з ГГФ, результати експериментів також свідчать про залежність процесів ембріогенезу від дії ГГФ. Встановлено, що організми $\epsilon$ надто чутливими до дії слабких електромагнітних полів, подібних до природних, у період ембріонального розвитку 17. Статистичні, біомедичні дослідження та експериментальні роботи підтверджують біологічні ефекти ГГФ напередодні й одразу після народження відносно різних систем організмів плоду й вагітних ${ }^{18}$. У результаті аналізу понад 1000 випадків народження недоношених дітей в Ізраїлі упродовж 1995-2002 pp. встановлена наявність позитивної кореляції між передчасними пологами і середньомісячною величиною сонячної активності ${ }^{19}$. На підставі аналізу більше 8000 історій пологів Н. Г. Гулюк встановив, що геомагнітні збурювання можуть провокувати передчасні пологи ${ }^{20}$. Згідно з результатами О. В. Сюткіної і співавторів, протягом перших тижнів після народження людини навколодобові ритми тільки розвиваються, в той час як навколо-7-добові біоритми домінують, причому вони синхронізовані саме з геомагнітною активністю, а не 3 ритмікою календарного тижня ${ }^{21}$. Дослідження Н. Качергене і Р. Верніцкайте показали, що організм новонародженого за параметрами біохімічних показників крові є більш чутливим до геокосмічних факторів, ніж до антропогенних 22 .

Таким чином, результати існуючих досліджень дії ГГФ доводять екологічну їх значущість для процесів раннього онтогенезу, в тому числі підвищення ризику захворіти на психічні та нервові розлади. Водночас практично відсутні дослідження впливу ГГФ на ранніх етапах онтогенезу осіб, які вчинили злочини, зокрема насильницькі. Проведення такого дослідження набуває сьогодні особливої актуальності, оскільки наближає нас до розуміння природи злочинної поведінки людини, процесу формування особистості злочинця та, у кінцевому підсумку, пізнання феномена злочинності взагалі.

Отже, мета роботи полягає у виявленні ймовірних геліогеофізичних факторів, які діють на етапах гаметогенезу, ембріогенезу та напередодні народження і можуть підвищити ризик схильності людини до злочинної поведінки. 
Для надійного й всеосяжного встановлення закономірностей дії ГГФ на організм слід ураховувати комплекс показників космічної погоди. Найбільш вагомі їі чинники - це геомагнітна активність (далі - ГМА), сонячна активність (СА), зміни полярності (знаку) міжпланетного магнітного поля (далі - ММП). Загальнопланетарні характеристики цих чинників адекватно відображуються геліогеофізичними індексами (що постійно вимірюються в мережі обсерваторій у різних регіонах світу і публікуються в друкованих та електронних каталогах відповідних установ), зокрема: $A p$ (показник ГМА); $F_{10.7}$ (показники СА), знак радіальної компоненти ММП, відношення геомагнітної активності до сонячної ГМА/СА (яке має сенс нормованого до прозорості іоносфери рівню збуреності магнітосфери), добуток геомагнітної активності на сонячну ГМА.СА (яке має сенс загальної геліогеофізичної збуреності). У нашому досліджені, враховуючи особливості вихідних даних, ми використовували добові, тижневі або річні показники цих індексів.

Якщо статистичний розподіл часових рядів індексів СА і ГМА відрізнявся від нормального, проводилася їх наближення до нормального розподілу за допомогою стандартних для таких випадків елементарних алгебраїчних перетворювань $23:(1)$

Якщо середньоарифметичні значення для окремих рядів істотно відрізнялись один від одного, проводилася стандартизація нормалізованих індексів за допомогою віднімання лінійної складової від кожного відрізка часового ряду та ділення результату на величину його середньоквадратичного відхилення, тобто переводилися у z-шкалу (шкалу нормованих відхилень від середніх оцінок) ${ }^{24}$. Математичне очікування такої величини дорівнює нулю, а дисперсія, відповідно, - одиниці. Таким чином нівелювався вплив на загальний результат викидів і довгоперіодичних варіацій у значеннях геліогеофізичних індексів.

Для визначення зв'язків фізіологічних та популяційних показників з геліогеофізичними індексами використовували метод накладених епох ${ }^{25}$, який дає змогу отримувати характерні профілі змін величин у певному діапазоні часу щодо однотипних подій: у даному випадку реперною (нульовою) точкою слугує час події, що трапилася; відносно неї назад і вперед у часі відраховуються значення геліогеофізичних індексів. Для оцінювання статистичної значущості тенденцій користувалися двобічним критерієм Вілкоксона ${ }^{26}$ на підставі того, що за потужністю критерій Вілкоксона наближається до t-критерію Ст'юдента. Критерій Вілкоксона $є$ результативним при розподілах статистичної величини як близьких до нормального, так і далеких від нормального, коли t-критерій Ст'юдента не виявляє значущих відмінностей ${ }^{27}$.

Ще один ефективний спосіб визначення ефектів ГГФ - це розгляд розподілу частот біологічно значущих подій або змін фізіологічних показників у певному діапазоні часу стосовно дат проходження специфічних геліогеофізичних подій різних класів, серед яких найбільш біоефективними є геомагнітні збурення та зміни знака ММП.

Геліогеофізичні дані (часові ряди геліогеофізичних індексів, геліогеофізичних подій різних класів 3 вичерпною інформацією про їх особливості) отримані із джерел міжнародної системи Світового центру геофізичних даних (США, Російська Федерація) ${ }^{28}$ та Інституту земного магнетизму, іоносфери і розповсюдження радіохвиль $\mathrm{PAH}^{29}$.

По-перше, динаміка індексів космічної погоди була проаналізована протягом гаметогенезу (період, який охоплює дозрівання батьківських яйцеклітин і сперматозоїдів), ембріогенезу (період внутрішньоутробного розвитку людини) і перших двох тижнів після народження - для вибірки злочинців і відповідної популяційної (контрольної) вибірки.

Група порівняння (дати народження злочинців, які скоїли умисні вбивства) становила 1962 особи, середній вік яких на момент скоєння злочину досяг $33,0 \pm 12,6$ років. Вони були народжені в різних регіонах України, переважно на території АР Крим і м. Севастополя. Дати скоєння ними злочинів переважно охоплюють період 2002-2012 років 30 .

Як контрольна група методом випадкового відбору на підставі даних місцевих відділів державної реєстрації актів цивільного стану була відібрана група осіб (15 275 випадків), ідентична (відповідно до розподілу за місцем і рокам народження) групі порівняння. Всі персональні дані попередньо знеособлювалися.

У статистичних даних відсутня інформація, що допомагає достовірно встановити термін зачаття, інформація щодо якого необхідна, оскільки реперною точкою служить саме дата зачаття. Для встановлення можливості використання цих даних було проведено статистичне дослідження. За даними аналізу репрезентативної вибірки статистичних даних пологових будинків АР Крим за період, відповідний датам народження осіб із групи порівняння, у 62 \% випадків строк від зачаття до пологів знаходиться в інтервалі 37,5-38,5 тижнів, а у 82 \% - в інтервалі 37-39 тижнів. Отже, можна вибрати період дискретизації геліогеофізичних даних, який дорівнює одному тижню, тим більше, що такою є стандартна одиниця числення строку гестації; а при аналізі вибірок брати до уваги результати цього статистичного дослідження.

У кожному з випадків ймовірна дата зачаття слугувала реперною точкою. Подальшу обробку здійснювали за допомогою методу накладених епох із використанням середніх (за тиждень) нормалізованих значень космофізичних індексів. 
Геомагнітна активність (рис. 1) і відношення геомагнітної активності до сонячної (рис. 2) є максимальними i достовірно вищими у групі злочинців, які скоїли умисні вбивства ( $<<0.01$ за критерієм Вілкоксона для непарних вибірок), ніж у контрольній групі, на другому тижні після тижня зачаття, тобто у середньому протягом 12-18 діб. Слід зазначити, що саме в цей час трапляється закладення нервової системи ембріона, і він є максимально чутливим до будь-яких стресових подій, які можуть вплинуть на структуру, що формується. Відомо, що підвищення геомагнітної активності та інфразвук $є$ несприятливими факторами, які можуть спричинити стрес як організму матері, так і безпосередньо ембріонові ${ }^{31}$.

Рис. 1. Геомагнітна активність (натуральний логарифм від Ар-індексу) протягом гаметогенезу й ембріогенезу злочинців у порівнянні з контрольної популяційною вибіркою.

Рис. 2. Відношення геомагнітної активності до сонячної як показник інтенсивності атмосферного інфразвуку протягом гаметогенезу й ембріогенезу злочинців у порівнянні з контрольної популяційною вибіркою.

Дані незалежних досліджень свідчать, що саме в цей термін пренатального розвитку підвищена геомагнітна активність у виборці осіб, які захворіли на комплекс післяпологової енцефалопатії ${ }^{32}$, а також у плодів, у яких проявились вроджені вади нервової системи ${ }^{33}$. Отже, у цей період нервова система $є$ надчутливою до зовнішніх впливів і, цілком можливо, що на організм осіб, які згодом скоїли умисні вбивства, мав місце вплив з боку факторів космічної погоди ще протягом 12-18 діб після їх запліднення. Звичайно, це означає, що цим впливом передається не схильність до вчинення злочинів, а деякі формально-динамічні характеристики нервової системи (імпульсивність, збудливість, брак регуляторних механізмів), які можуть у майбутньому обумовити готовність особи до реалізації насильницької злочинної поведінки.

Далі ми детально розглянули добову динаміку індексів космічної погоди навколо дат народження злочинців у порівнянні з їх динамікою для контрольної групи (від 15 діб перед народженням до 15 діб після 
народження). Виявилось, що у порівнянні з контрольною групою геомагнітна активність значно ( $<0.01$ за критерієм Вілкоксона для непарних вибірок) вище за добу до народження і в добу народження злочинців (рис. 3).

Рис. 3. Геомагнітна активність (логарифм Ар-індексу) протягом \pm 15 діб навколо дат народження злочинців та осіб з популяційної (контрольної) вибірки.

Ще одна тенденція, яка заслуговує уваги, це ймовірність переходу міжпланетного магнітного поля до негативної полярності i, взагалі, його негативна полярність за 1-2 доби до народження злочинців ( $<0.01$ за критерієм Вілкоксона для непарних вибірок), у порівнянні з контрольною (популяційною) вибіркою (рис. 4).

Рис. 4. Знак (полярність) радіальної компоненти міжпланетного магнітного поля протягом \pm 15 діб навколо дат народження злочинців та осіб з популяційної (контрольної) вибірки.

Слід зазначити, що за даними вітчизняних психіатрів ${ }^{34}$ особи, хворі на олігофренію, шизофренію та біполярний афективний розлад, частіше народжуються саме за умов максимуму геомагнітної активності та змінах знаку міжпланетного магнітного поля з позитивної на негативну полярність. Як свідчать результати нашого дослідження, подібні космофізичні умови спостерігаються й напередодні народження злочинців. Отже, з урахуванням статистичної значущості встановлених тенденцій можна вважати, що закономірності, надійно встановлені для осіб, які мають різного роду психічні розлади, повністю знаходять своє відображення й у статистиці народжень злочинців, які скоїли умисні вбивства.

У цілому отримані результати свідчать, що роль ГГФ у детермінації злочинної поведінки полягає, передусім, у їх впливі на етапах гаметогенезу, ембріогенезу і напередодні народження людини, як передумови формування (насамперед з боку формально-динамічних процесів у нервовій системі) готовності до реалізації насильницької, насамперед імпульсивної, злочинної поведінки. Оскільки досліджені фактори можуть під- 
вищити ризик схильності людини до злочинної поведінки, їх вплив можна (необхідно) використовувати для прогнозування злочинної поведінки людини на індивідуальному рівні, починаючи з раннього онтогенезу.

Отримані результати свідчать про виключну актуальність проведення подальших комплексних (на засадах консолідації «гуманітарного» та здобутків природничих наук, етології, екологічної фізіології та ін.) досліджень впливу геліогеофізичних та інших природних (екологічних) факторів на індивідуальну злочинну поведінку (передусім, тих іiї видів, що мають глибинну мотивацію зі значною роллю біологічних факторів: тероризм, тяжкі насильницькі злочини тощо) й стан злочинності взагалі. Теоретична і практична значущість наукового пошуку в даному напрямі обумовлена тим, що такого роду кримінологічні дослідження наближають нас до розуміння біосоціальної природи злочинної поведінки, а отже, й до пізнання феномена злочинності в цілому.

${ }^{1}$ Игнатов А. Н. Природные факторы детерминации преступности: постановка проблемы / А. Н. Игнатов // Криминология: вчера, сегодня, завтра. Журнал Санкт-Петербуржского криминологического клуба. - 2011. - № 4 (23). - СПб., 2011. - С. $22-27$.

2 Dimitrov $B$. D. Suicides and birthdate: a hypothesis for heliogeophysical imprinting in psychiatric patients / Dimitrov B. D., Semerdjieva M., Madjirova N. // Folia Med (Plovdiv). - 1998. - 40 (3A). - P. 135-136; Ertel S. Space weather and revolutions: Chizevsky's heliobiological claim scrutinized / Suitbert Ertel // Studia psychologica. - 1996. - Vol. 38. - № 1-2. - P. 3-22.

3 Бучаченко А. Л. Новые механизмы биологических эффектов электромагнитных полей / Бучаченко А. Л., Кузнецов Д. А., Бердинский В. Л. // Биофизика. - 2006. - Т. 51. - С. 545-552.

${ }^{4}$ Шабатура Н. Н. Механизм происхождения инфрадианных биологических ритмов / Шабатура Н. Н. // Успехи физиол. наук. - 1989. - Т. 20, № 3. - С. 83-103.

${ }^{5}$ Gordon C. The effect of geomagnetic storms on suicide / Charmaine Gordon, Michael Berk // S. Afr. Psychiatry Rev. - 2003. № 6. - P. 24-27; Kay R. W. Geomagnetic Storms: Association with Incidence of Depression as Measured by Hospital Admission / Ronald W. Kay // British Journal of Psychiatry. -1994. - Vol. 164. - P. 403-409.

${ }^{6}$ Environmental and geomagnetic factors in relation to selfdestructive ideation and behavior / Bergiannaki J. D., Tritakis V. P., Psarros C. [et al] // Proc. XX Congr. IASP. - Athens, 1999. - P. 140-141.

7 Влияние условий Крайнего Севера на уровень убийств при гелиогеофизических возмущениях / Лизунов Ю. В., Серпов В. Ю., Храмов А. В. [и др.] // Экология человека. - 2006. - № 7. - С. 9-13.

8 Григорьев П. Е. Эффекты космической погоды в террористической активности / Григорьев П. Е., Владимирский Б. М. // Ученые записки Таврического национального университета им. В. И. Вернадского. Серия «Биология, химия». - 2007. - Т. 20 (59), № 1. - С. 28-46; Григор'єв П. Є. Космофізичні чинники суїцидальної і терористичної активності / П. С. Григор'єв, В. А. Розанов, О. М. Ігнатов // Протидія ксенофобії, екстремізму і тероризму у сучасному суспільстві: Наукові праці Міжнародної науково-практичної конференції / За заг. ред. Ігнатова О. М.; Інститут економіки та права (філія) ОУП ВПО «Академія праці та соціальних відносин» в м. Севастополі. - Сімферополь: КРП «Видавництво «Кримнавчпеддержвидав», 2012. - С. 236-241.

${ }_{9}^{9}$ Волчек О. Д. Адаптивные типы человека во времени / Волчек О. Д. // Космос и биосфера : VII междунар. конф., 1-6 окт. 2007 г. : тезисы докл. - К., 2007. - С. 86-87.

10 Imprinting mechanisms / Constancia M., Pickard B., Kelsey G. [et al] // Genome Res. - 1998. - Vol 8, № 9. - P. 881-900; Kelsey G. Analysis and identification of imprinted genes / Kelsey G., Reik W. // Methods. - 1998. - Vol. 14, № 2. - P. $211-234$.

11 Хорсева Н. И. Сравнение индивидуально-типологических особенностей людей, рожденных в разные годы 21-23 циклов солнечной активности / Н. И. Хорсева, Т. А. Зенченко // Космос и биосфера : VI междунар. конф., 26 сентября - 1 октября 2005 г. : тезисы докл. - Партенит, 2005. - С. 76.

12 Исхаков В. П. К вопросу о возможной связи между шизофренией и солнечной активностью / Исхаков В. П. // Живые системы и гелиогеофизические факторы. МОИП. - М. : Наука, 1976. - С. 13-16.

13 Корнетов А. Н. Ритмологические и экологические исследования при психических заболеваниях / Корнетов А. Н., Самохвалов В. П., Корнетов Н. А. - К. : Здоровья, 1988. - 205 с.

14 Исхаков В. П. Гипотеза пренатальной космофизической этиологии эндогенных психозов // Межд. конф., посвященная 105-летию со дня рожд. А. Л. Чижевского: материалы; РАКЦ, ГИ, МАН (УР), МИГАиК. - М.: ИИКЦ «Эльф-З», ЗБФ «Гелиос», 2002. - C. 191-195; Richardson-Andrews R. C. The sunspot theory of schizophrenia: Further evidence, a change of mechanism, and a strategy for the elimination of the disorder / R. C. Richardson-Andrews // Med. Hypotheses. - 2009. - Vol. 72. - № 1. - P. 95-98.

15 Effect of geomagnetic field changes on the rate of spontaneous chromosome aberrations in human somatic cells / Chebotarev A. N., Bochkov N. P., Oraevskii V. N. [et al] // Dokl. Biol. Sci. - 2002. - № 3. - P. 263-266.

16 Антипенко $E$. H. Обоснование необходимости и возможности изучения генетической опасности физических факторов низкоэнергетической природы / Антипенко Е. Н., Тимченко О. И. // Гигиена и санитария. - 1989. - № 10. - С. 59-62.

17 Lenguel J. Further observation on the biological effect of the magnetic field / Lenguel J. // Arch exptl. Zellforschung (Iena). 1994. - № 15. - Р. 250; Суслова Г. Ф. Влияние геомагнитных факторов на физическое развитие и патологию человека и животных / Суслова Г. Ф., Петричук С. В., Беневоленский В. Н. // Хронобиология сердечно-сосудистой системы. - М. : Изд. ун-та Дружбы Народов им. Патриса Лумумбы, 1988. - С. 91-92.

18 Persinger M. A. Geophysical variables and behavior: LXXXVI. Geomagnetic activity as a partial parturitional trigger - are male babies more affected than female babies? / Persinger M. A., Hodge K. A. // Percept. Mot. Skills. - 1999. - Vol. 88, № 3, Part 2. P. 1177-1180; O'Connor R. P. Geophysical variables and behavior: LXXXV. Sudden infant death, bands of geomagnetic activity, and Pc1 (0.2 to 5 HZ) geomagnetic micropulsations / O’Connor R. P., Persinger M. A. // Percept. Mot. Skills. - 1999. - Vol. 88. - № 2. P. 391-397; Eckert E. E. Magnetic influences on fetus and infant as reason for Sudden Infant Death Syndrome: A new testable hypothesis / Eckert E. E. // Med. Hypotheses. - 1992. - № 38. - P. 66-69.

${ }^{19}$ Monthly number of preterm births and environmental physical activity / Stoupel E., Sirota L., Osovsky M. [et al] // J. Basic. Clin. Physiol. Pharmacol. - 2007. - Vol. 18. - № 2. - P. 149-157.

20 Гулюк Н. Г. Влияние солнечной активности, вариации земного магнетизма и других факторов космического и геофизического происхождения на ритмику родов и цикличность менструации у женщин / Гулюк Н. Г. // Актуальные вопросы акушерства и гинекологии. - Ужгород, 1965. - С. 295-323. 
${ }^{21}$ Neonatal intensive care may consider associations of cardiovascular rhythms with local magnetic disturbance / Syutkina E. V., Cornelissen G., Grigoriev A. E. [et al] // Scripta medica. - 1997. - Vol. 70. - P. 217-226.

22 Верницкайте Р. Группа риска внутриутробного инфицирования как индикатор внешней среды / Верницкайте Р., Качергене Н., Нарциссов Р. П. // Слабые и сверхслабые поля и излучения в биологии и медицине: II Межд. Конгр.; 3-7 июля 2000 г., СПб. : тез. докл. - СПб., 2000. - С. 267-268.

${ }_{23}$ Petrie A. Medical Statistics at a Glance / Aviva Petrie \& Caroline Sabin. - UK : Blackwell Publishing, 2005. - P. 24.

${ }^{24}$ Larsen R. J.-M. An introduction to mathematical statistics and its applications; [4th ed] / Larsen Richard J.-Marx, Morris L. Upper Saddle River, NJ : Pearson Prentice Hall, Pearson Education Internacional, 2006. - P. 282.

${ }_{25}$ Мустель Э. Р. Метод наложения эпох / Мустель Э. Р. // Бюлл. Науч. информ. астроном. совета АН СССР. - 1968. № 10. - C. 8 .

26 Wilcoxon F. Individual comparisons by ranking methods / F. Wilcoxon // Biometrica Bulletin. - 1945. - № 1. - P. 80-83. C. 243.

27 Варден Б. Л. Математическая статистика / Б. Л. ван дер Варден. - М. : Изд. Иностранной литературы, 1960. - 435 с. -

28 Офіційний сайт Світового центру геофізичних даних (США, Російська Федерація) [Електронний ресурс]. - Режим доступу: http://www.ngdc.noaa.gov/wdc/

29 Офіційний сайт Інституту земного магнетизму, іоносфери і розповсюдження радіохвиль РАН [Електронний ресурс]. Режим доступу: http://www.izmiran.ru/services/saf/

30 Інформація Управління інформаційно-аналітичного забезпечення ГУМВС України в АР Крим за даними довідок про наслідки розгляду кримінальних справ (за ст. 115 КК України) судом (форма 6) за 2002-2013 рр.

31 Хорсева Н. И. Возможная роль гелиогеофизических факторов в развитии симптомокомплекса послеродовой энцефалопатии / Хорсева Н. И., Григорьев П. Е. // Геофизические процессы и биосфера. - 2005. - Т. 4. - № 1. - С. 98-101.

32 Там само.

33 Григорьев П. Е. Гелиогеофизические факторы риска возникновения пороков нервной трубки / П. Е. Григорьев // Авиакосмическая и экологическая медицина. - 2008. - № 4. - С. 63-66.

34 Самохвалов В. П. Эффекты космофизических флуктуаций при психических заболеваниях / Самохвалов В. П. // Проблемы космической экологии. - 1989. - Т. 65. - С. 65-80; Самохвалов В. П. Эволюционная психиатрия / Самохвалов В. П. Симферополь : ИМИС - НПФ «Движение» Лтд., 1993. - С. 130-133.

\section{Резюме}

Ігнатов О. М. Григор'єв П. С. Можливий вплив геліогеофізичних факторів на організм майбутніх злочинців у ранньому онтогенезі.

У статті розглядаються результати дослідження, присвяченого виявленню ймовірних геліогеофізичних факторів, які діють на ранніх етапах онтогенезу (гаметогенезу, ембріогенезу і напередодні народження) і можуть підвищити ризик схильності людини до злочинної поведінки.

Ключові слова: геліогеофізичні фактори, онтогенез, поведінка, злочинність, вбивство.

\section{Резюме}

Игнатов А. Н., Григорьев П. Е. Возможное влияние гелиогеофизических факторов на организм будущих преступников в раннем онтогенезе.

В статье рассматриваются результаты исследования, посвященного выявлению вероятных гелиогеофизических факторов, действующих на ранних этапах онтогенеза (гаметогенеза, эмбриогенеза и накануне рождения), которые могут повысить риск склонности человека к преступному поведению.

Ключевые слова: гелиогеофизическая факторы, онтогенез, поведение, преступность, убийство.

\section{Summary}

Ignatov A., Grigoriev P. Possible influence of heliogeophysical factors on organism of the criminals during their early ontogenesis.

The article discusses the results of a study on the identification of probable heliogeophysical factors at early stages of ontogenesis (gametogenesis, embryogenesis and on the eve of birth), and may increase the risk of human propensity to criminal behavior.

Key words: heliogeophysical factors, ontogeny, behavior, crime, murder. 